\title{
IDH1 NM_005896.3:C.356G>A
}

National Cancer Institute

\section{Source}

National Cancer Institute. IDH1 NM 005896.3:C.356G >A. NCI Thesaurus. Code C131102.

A nucleotide substitution at position 356 of the coding sequence of the IDH 1 gene where guanine has been mutated to adenine. 